included in the 1990 general practitioner contract adopting it for accreditation smacks of double counting, and there is little evidence that it is associated with better performance. Selecting and monitoring educational events and monitoring attendance - let alone how much learning actually goes onwould be difficult.

The third approach is to measure general practitioners' performance in their practice. Difficult and expensive, it requires national agreements on standards of performance, objective measurements, and visiting teams. It is, however, the one method that is already operating in general practicethrough visits to approve trainers and to accredit members of the Royal College of General Practitioners as fellows. The survey earlier this year found that more than two fifths of general practitioners reported that their practice participated in training and so were being assessed.'

The survey also found that general practitioners have a preference regarding how they might be reaccredited: they would clearly prefer peer reviewed practice visits with external visitors. ${ }^{1}$ Their responses were also analysed according to their degree of involvement in training - from no involvement, through training provided in the practice, to providing training personally. A clear gradient existed: the greater the general practitioner's participation in training the more likely he or she was to believe that reaccreditation was necessary. Trainers, who are reaccredited for teaching at least every five years and in some regions every three, value reaccreditation most.

General practitioners have given their representatives an effective mandate to put reaccreditation on their national agenda. Many groups, such as patients and managers, may now try to get in on the act. They would, however, be wise to stand back: this is a delicate time when the first shoots of a new growth could easily be damaged. General practice has taken the first step: it should now be encouraged and allowed to work out its own solution, probably by peer review. It must, for example, construct a sensitive, educational, and appropriate system for those who have problems in being reaccredited.

Three groups have a stake in this: the General Medical Services Committee, which organised the survey; the Royal College of General Practitioners, which developed vocational training ${ }^{6}$ and higher professional education in general practice ${ }^{7}$ and published the most advanced system of reaccreditation in general practice, Fellowship by Assessment ${ }^{8}$; and the university appointed regional advisers in general practice, who are already reaccrediting about two in five British general practices.

In the mid-1970s general practice needed to invent a new organisation, the Joint Committee on Postgraduate Training for General Practice, to handle vocational training. Could the three national groups with an interest in reaccreditation now get together, share their skills, and take the process forward?

Professor of General Practice and Director,

DENIS PEREIRA GRAY

Postgraduate Medical School,

Exeter University,

Exeter EX2 5DW

1 Electoral Reform Ballot Services. Your choices for the future. London: GMSC, 1992:99-104.

2 Pereira Gray D. Accreditation in general practice. Quality in Health Care 1992;1:61-4.

3 Pereira Gray D. Qualifications and quality of care. Lancet 1991;337:1025.

4 Refunds are for MRCGPs only. General Practitioner 1991 April 6:1.

5 Royal College of Obstetricians and Gynaecologists. Report of the RCOG working party on continuing medical education. London: RCOG, 1991.

6 College of General Practitioners. Special vocational training for general practice. Report from general practice 1. London: CGP, 1965.

Royal College of General Practitioners. A college plan. Priorities for the future. London: RCGP, 1990:32-42. (Occasional paper 49.)

8 Royal College of General Practitioners. Fellowship by assessment. London: RCGP, 1990. (Occasional paper 50.)

\title{
Osteoporosis in men
}

\section{Hormonal protection eventually fades and prevention is key}

Clinical osteoporosis may be defined as thinning of the bonewith normal mineralisation - severe enough to lead to fracture with minimal trauma. The incidence of vertebral fractures is up to six times less common in men than women, ${ }^{1}$ but osteoporosis and its problems are on the increase in both sexes. Men are relatively protected for several reasons.

Firstly, age for age their bone density is higher. Their bones are bigger; and they continue to increase in size owing to growth of periosteal bone. ${ }^{2}$ Androgens have a direct effect on bone cells, probably in conjunction with insulin related growth factor I, on chondrocytes of the growth plate, and on osteoblasts. ${ }^{3}$ The anabolic effect of testosterone on muscles probably increases the stresses on bones during exercise, and this in turn would be expected to lead to more deposition of bone in men.

Secondly, spermatogenesis is a production line process that does not progressively deplete the stock of germ cells; normally therefore, both the structure and function of the seminiferous tubules, which are important for the function of Leydig cells, are maintained into quite advanced old age. The production of testosterone (and oestradiol) is well sustained in old men. ${ }^{+}$This hormone pattern contrasts with the single batch process of oogenesis in women, which means that once stocks are depleted production of oestradiol virtually ceases - with the consequent menopausal acceleration of bone loss.
Thirdly, and probably as an adverse consequence of high concentrations of testosterone on other body systems, men on average live about five years less than women, so there are fewer old men to develop cortical osteoporosis and so to sustain fractures of the neck of the femur. The pattern of osteoporosis in men is different from that in women, with less loss of trabeculae and thinning of trabeculae being more prominent..$^{56}$

Except in extreme old age, men with osteoporosis generally present with pain due to vertebral crush fractures. Several studies have shown that identifiable risk factors play a more prominent part than in women. These include predisposing illnesses - any condition leading to treatment with steroids or excess natural secretion of these hormones, hypogonadism (with or without hyperprolactinaemia), gastrointestinal surgery, defective synthesis of type I collagen leading to osteogenesis imperfecta tarda, and, rarely, systemic mastocytosis. ${ }^{6-11}$ A clinician in doubt about the diagnosis should measure the serum concentrations of luteinising hormone, follicle stimulating hormone, testosterone, and prolactin and do screening tests for Cushing's syndrome such as measurements of the 24 hour urinary free cortisol excretion and serum cortisol concentration after suppression the previous night with a single dose of $1.5 \mathrm{mg}$ dexamethasone. Behavioural risk factors include heavy cigarette smoking, excessive drinking, a low calcium diet (which may result from alactasia), and 
inactivity. ${ }^{1}$ Obesity is apparently protective in men in middle and old age. ${ }^{\prime}$

Just how and why bone is lost in these conditions are far from clear. Steroids apparently act by directly inhibiting formation of bone while osteoclastic resorption continues unchecked. ${ }^{12}$ Most of the loss of vertebral bone occurs during the first six months of treatment and seems to be due principally to thinning of trabeculae with minimal perforation. Simple and effective regimens are urgently needed that would protect against bone loss in men (and women) given pharmacological doses of steroids.

In hypogonadism the pattern seems to be one of trabecular perforation rather than thinning, and treatment with androgens seems to arrest and partially reverse bone loss. ${ }^{813}$ Francis et al found that serum concentrations of calcitriol (the active metabolite of vitamin D) and absorption of radiolabelled calcium were low in hypogonadal men with osteoporosis ${ }^{8}$ and rapidly returned to normal with treatment with testosterone. ${ }^{9}$ These findings were not, however, confirmed by Jackson et al, who concluded that the effect was seen only in conditions of borderline vitamin $\mathrm{D}$ deficiency with low concentrations of 25 hydroxyvitamin $\mathrm{D}$, as are seen in more extreme latitudes. ${ }^{6}$

The picture is complicated in gastrointestinal disease, which usually predisposes to osteomalacia-it may lead to mixed osteoporosis and osteomalacia. Malabsorption of calcium leads to secondary hyperparathyroidism, which in turn leads to increased renal production of calcitriol and accelerated hepatic degradation of its precursor, calcidiol. ${ }^{14} 15$ Malabsorption may also lead to deficiencies of protein and of vitamin $\mathrm{K}$, which is necessary for normal synthesis of the important bone matrix protein osteocalcin. ${ }^{16}$

How cigarette smoking predisposes to osteoporosis is not clear. The effect may in part be due to reduced body weight and inactivity in heavy smokers. Alcohol seems to be more important ${ }^{18}$; in addition to leading to cirrhosis and malnutrition it has a direct inhibitory effect on osteoblasts in vitro. ${ }^{19}$ Self evidently, being drunk is a risk factor for sustaining fractures. Most fractures of the femoral neck in patients with osteoporosis occur during a fall, and prevention is important - for example, by looking at drug treatment.

The protective effect of the testicular hormones does not last for ever. Most studies have been cross sectional, and it is unclear how much bone normal men lose at what age; one prospective study on men (who did not take regular exercise) found rates of $1 \%$ a year for radial bone and $2-3 \%$ for vertebral bone. ${ }^{20}$ Very old men have an accelerated rate of bone lossthrough declining testosterone concentrations, aging of bone cells, and inactivity - and their incidence of hip fracture from the mid-80s onwards is similar to that in women. ${ }^{21}$

The actual number of men sustaining hip fractures in Britain (and probably elsewhere) is about a fifth that of women, but the incidence is increasing. Data obtained in Hong Kong, where osteoporosis was once rare, ${ }^{22}$ by Lau and her colleagues indicate that urbanisation increases the numbers of hip fractures in both sexes..$^{23-25}$ In men aged 80 and over the age specific incidence increased from three to nine per 1000 between 1966 and 1989 in men and from seven to 13 per 1000 over the same time in women. ${ }^{23}$

A low intake of calcium seems to be harmful, and calcium seems to be an independent determinant of axial bone mass. ${ }^{2326}$ The relative risk for hip fracture in elderly patients with the lowest quintile of calcium intake was 2.9 in a case-control study - but almost as much of the risk $(2 \cdot 1)$ was related to inactivity. ${ }^{23}$ The importance of physical exercise, regardless of underlying hormone status, is shown by the finding that in parts of rural Turkey where the women do all the physical work osteoporotic fractures are commoner in men than women (J A Kanis, personal communication).

Despite the proliferation of conferences on osteoporosis and the range of treatments available it is by no means clear how the disease should be prevented or treated in men or women. Clearly an adequate calcium intake $(>500 \mathrm{mg} / \mathrm{day})$ and plenty of exercise in youth are important in building up and sustaining a well mineralised skeleton, and hypogonadism should be treated.

For men taking steroids simple short regimens of bisphosphonates seem likely to become an important adjunct to protect bone. ${ }^{12}$ The same may apply to patients during enforced immobilisation..$^{27}{ }^{28}$ But for large scale prevention we will have to direct public health programmes towards healthy eating, including (at least in Europe) supplements of calcium and vitamin $\mathrm{D}$ and a programme of the right kind of exercise (whatever that is) sustained into old age-with the dual benefit of sustaining bone density and structure and maintaining the reflexes necessary to break a fall.

Professor of Medicine,

DAVID GANDERSON

Chinese University of Hong Kong,

Prince of Wales Hospital,

Shatin, NT,

Hong Kong

1 Seeman E, Melton LJ III, O'Fallon WM, Riggs BL. Risk factors for spinal osteoporosis in men. Am F Med 1983;75:977-83.

2 Mosekilde L, Mosekilde L. Sex differences in age-related changes in vertebral body size, density and biomechanical competence in normal individuals. Bone 1990;11:67-73.

3 Zapf J, Schmid C, Froesch ER. Biological and immunological properties of insulin-like growth factors (IGF). Clinics in Endocrinology and Metabolism 1984;13:3-30.

4 Vermeulen A, Rubens R, Verdonck L. Testosterone secretion and metabolism in male senescence. f Clin Endocrinol Metab 1972;34:730-5.

5 Parfitt AM, Mathews CHE, Villanueva AR, Kleerekoper M, Frame B, Rao DS. Relationships between surface, volume and thickness of iliac trabecular bone in aging and in osteoporosis. f Clin Invest 1983;72:1396-409.

6 Jackson JA, Kleerekoper M, Parfitt AM, Rao DS, Villanueva AR, Frame B. Bone histomorphometry in hypogonadal and eugonadal men with spinal osteoporosis. $\mathcal{F}$ Clin Endocrinol Metab 1987;65:53-8.

Greenspan SL, Neer RM, Ridgway EC, Klibanski A. Osteoporosis in men with hyperprolactinemic hypogonadism. Ann Intern Med 1986;104:777-82.

8 Francis RM, Peacock M, Aaron JE, Selby DL, Taylor GL, Thompson J, et al. Osteoporosis in hypogonadal men: role of decreased plasma 1,25-dihydroxyvitamin D, calcium malabsorption, and low bone formation. Bone 1986;7:261-8.

9 Francis RM, Peacock M, Marshall DH, Horsman A, Aaron JE. Spinal osteoporosis in men. Bone Miner 1989;5:347-57.

10 Webb TA, Li C-Y, Yam LT. Systemic mast cell disease: a clinical and hematopathologic study of 26 cases. Cancer 1982;49:927-38.

11 Parfitt AM, Pødenphant J, Villanueva AR, Frame B. Metabolic bone disease with and without osteomalacia after intestinal bypass surgery: a bone histomorphometric study. Bone 1985;6:211-20.

12 Reid DM. Corticosteroid-induced osteoporosis. In: Smith R, ed. Osteoporosis 1990. London: Royal College of Physicians, 1990;99-117.

13 Baran DT, Bergfeld MA, Teitelbaum SL, Avioli LV. Effect of testosterone therapy on bone formation in an osteoporotic hypogonadal male. Calcif Tissue Res 1978;26:103-6.

14 Clements MR, Johnson L, Fraser DR. A new mechanism for induced vitamin D deficiency in calcium deprivation. Nature 1987;325:62-5.

15 Clements MR, Davies M, Fraser DR, Lumb GA, Mawer EB, Adams PH. Metabolic inactivation of vitamin $\mathrm{D}$ is enhanced in primary hyperparathyroidism. Clin Sci 1987;73:659-64.

16 Price PA, Parthemore JG, Deftos LJ. New biochemical marker for bone metabolism. Measurement by radioimmunoassay of bone GLA protein in the plasma of normal subjects and patients with by radioimmunoassay of bone GLA protein in

17 Brown JP, Delmas PD, Malaval L, Edouard C, Chapuy MC, Meunier PJ. Serum bone-Gla protein a specific marker for bone formation in post-menopausal osteoporosis. Lancet 1984;i:1091-3.

8 Bikle DD, Genant HK, Cann C, Recker RR, Halloran BP, Strewler GJ. Bone disease in alcohol buse. Ann Intern Med 1985;103:42-8.

19 Diamond T, Stiel D, Lunzer M, Wilkinson M, Posen S. Ethanol reduces bone formation and may cause osteoporosis. Am $\mathrm{F}$ Med 1989;86:282-8.

20 Orwoll ES, Oviatt SK, McClung MR, Deftos LJ, Sexton G. The rate of bone mineral loss in normal men and the effects of calcium and cholecalciferol supplementation. Ann Intern Med 1990;112:29-34.

21 Lips P, van Ginkel FC, Netelenbos JC, Wiersinga A, van der Vijgh WJ. Lower mobility and markers of bone resorption in the elderly. Bone Miner 1990;9:45-57.

22 Chalmers J, Ho KC. Geographical variation in senile osteoporosis. The association with physical activity. F Bone foint Surg [Br] 1970;52:667-75.

23 Lau E, Donnan S, Barker DJP, Cooper C. Physical activity and calcium intake in fracture of the proximal femur in Hong Kong. BMf 1988;297:1441-3.

24 Lau EM, Donnan SP. Falls and hip fracture in Hong Kong Chinese. Public Health 1990;104: $117-21$

25 Woo J, Lau E, Swaminathan R, Pang CP, MacDonald D. Biochemical predictors for osteoporotic fractures in elderly Chinese-a longitudinal study. Gerontology 1990;36:55-8.

26 Kelly PJ, Pocock NA, Sambrook PN, Eisman JA. Dietary calcium, sex hormones, and bone mineral density in men. BMF 1990;300:1361-4.

27 Minaire P, Neunier P, Edouard C, Bernard J, Courpon P, Bouret J. Quantitative histological dat on disuse osteoporosis: comparison with biological data. Calcif Tissue Res 1974;17:57-73.

$28 \mathrm{Krolner}$ B, Toft B. Vertebral bone loss: an unheeded side effect of therapeutic bed rest. Clin Sci 1983;64:537-40. 